\title{
Nilai Total Ketidakteraturan Titik pada Graf Series Parallel $\mathbf{s p}(\mathbf{m}, 3,3)$
}

\author{
Riskawati \\ Universitas Muslim Maros, riskawati@umma.ac.id \\ Erniwati Jalil \\ Universitas Muslim Maros, ernijalil@umma.ac.id
}

Susi Ekawati

Universitas Muslim Maros, susiekawati31@gmail.com

\begin{abstract}
ABSTRAK, Penelitian ini membahas tentang penentuan nilai total ketidakteraturan titik pada Graf Series Parallel $s p(m, 3,3)$. Penentuan nilai total ketidakteraturan titik pada Graf Series Parallel $s p(m, 3,3)$ dilakukan dengan menentukan batas bawah terbesar dan batas atas terkecil. Batas bawah dianalisis berdasarkan sifat-sifat graf dan Teorema pendukung lainnya, sedangkan batas atas dianalisis dengan pemberian label pada titik dan sisi pada Series Parallel. Berdasarkan hasil penelitian ini diperoleh nilai total ketidakteraturan titik pada graf Series Parallel $\operatorname{tvs}(\operatorname{sp}(m, 3,3))=3 m+1$, untuk $m \geq 3$.
\end{abstract}

Kata Kunci: Graf Series Parallel, Pelabelan Total, Nilai Total Ketidakteraturan Titik

\section{PENDAhuluan}

Penelitian mengenai teori graf terus mengalami perkembangan. Salah satu pembahasan yang terus berkembang adalah pelabelan pada graf. Objek kajiannya berupa graf yang secara umum direpresentasikan oleh titik dan sisi serta himpunan bagian bilangan asli yang disebut label. Pelabelan graf diperkenalkan oleh Stewart (1966), kemudian Kotzig dan Rosa (1970).

Wallis (2001) mendefinisikan pelabelan pada suatu graf sebagai suatu fungsi yang memetakan unsur-unsur graf ke suatu himpunan bilangan. Suatu pelabelan dengan domain berupa himpunan titik dari suatu graf disebut pelabelan titik, sedangkan pelabelan dengan domain berupa himpunan sisi dari suatu graf disebut pelabelan sisi. Apabila domain dari pemetaan tersebut adalah gabungan himpunan titik dan himpunan sisi maka pelabelan tersebut dinamakan pelabelan total.

Pelabelan sisi dan titik dari graf dapat dilakukan dengan banyak cara. Salah satu cara yang dapat digunakan adalah melabelinya dengan bilangan. Ada banyak pelabelan graf yang telah dikembangkan, diantaranya adalah pelabelan gracefull, pelabelan harmoni, pelabelan total tidak teratur, pelabelan ajaib dan pelabelan anti ajaib.

Penentuan nilai total ketidakteraturan titik pada beberapa jenis graf telah dilakukan oleh beberapa ahli. Rajaningsih, I. dkk (2012), menentukan nilai total ketidakteraturan titik pada graf barisan segitiga. Ahmad, A. dkk (2014) menentukan nilai total ketidakteraturan titik pada beberapa kelas graf uncyclic. Nurdin dkk. (2010) menentukan nilai total ketidakteraturan titik pada graf pohon. Untuk graf regular, yaitu graf yang semua titiknya memiliki derajat yang sama, beberapa hasil telah ditemukan. Nilai total ketidakteraturan titik untuk graf lingkaran telah ditemukan oleh Baca, M. dkk (2007). Begitu pula untuk graf prisma, pada tahun 2014, Ahmad, A. telah menentukan nilai total ketidakteraturan titik pada graf prisma.

Graf series parallel merupakan pengembangan dari graf theta yang diperumum. Karakteristik menarik dari graf series parallel adalah sebagian anggota himpunan titiknya berderajat dua. Beberapa peneliti telah menentukan nilai ketidakteraturan pada graf series parallel. Pada tahun 2015, Rajasingh, I. telah menentukan nilai total ketidakteraturan sisi pada graf series parallel . selanjutnya pada tahun 2019, Riskawati dkk menentukan nilai total ketidakteraturan titik pada graf series parallel $s p(m, r, 2)$ dan Marzuki dkk. (2020) telah menentukan nilai total ketidakteraturan titik pada graf series parallel $s p(m, 1,3)$ Oleh karena itu, penelitian ini akan difokuskan pada penentuan nilai total ketidakteraturan titik pada graf series parallel $s p(m 3,3)$. 


\section{TINJAUANPUSTAKA}

Pada bagian ini diberikan beberapa definisi dan konsep dasar pada teori graf, terminologi graf, jenis-jenis graf serta penjelasan mengenai pelabelan pada graf

\section{Pengertian Graf}

Teori graf pertama kali diperkenalkan oleh Leonhard Euler pada tahun 1736. Graf merupakan pasangan himpunan titik dan himpunan sisi. Pengaitan titik-titik pada graf membentuk sisi dan dapat direpresentasikan sebagai suatu gambar.

Definisi 1 Graf $G$ merupakan suatu pasangan himpunan $(V, E)$ dimana $V$ suatu himpunan tak kosong dan $E$ (mungkin kosong). Himpunan $E$ merupakan himpunan pasangan tak terurut dari elemen $V$. Elemen $V$ disebut titik dari $G$ dan elemen $E$ disebut sisi dari $G$.

Graf $G$ dengan himpunan titik $V$ dan himpunan sisi $E$ dinotasikan dengan $G=$ $(V, E)$. Sisi pada graf digambarkan sebagai garis yang kedua ujungnya merupakan titik dinyatakan dengan $e=u v$. Banyaknya unsur dari $V(G)$ disebut order dari $G$ dan banyaknya unsur dari $E(G)$ disebut ukuran (size) dari $G$.

\section{Terminologi Graf}

Dalam mempelajari graf terdapat beberapa terminologi yang berkaitan dengan graf. Berikut didefinisikan beberapa teminologi graf.

Definisi 2 Dua buah titik pada graf dikatakan bertetangga (adjacent) bila keduanya dihubungkan oleh sebuah sisi. Dengan kata lain, $u$ bertetangga dengan $v$ jika (uv) adalah sebuah sisi pada graf $G$.

Definisi 3 Misalkan graf $G$ dan $\{u, v\} \in V(G)$, jika $e=(u v) \in E(G)$ maka sisi $e$ dikatakan terkait (incident) dengan titik $u$ dan titik $v$.

Definisi 4 Misalkan $v$ adalah titik dalam suatu graf $G$. Derajat titik $v$ adalah banyaknya sisi yang terkait dengan titik $v$, dinotasikan dengan $\operatorname{deg}(v)$, dimana $\Delta(G)$ merupakan derajat maksimum titik dari $G$ dan $\delta(G)$ merupakan derajat minimum titik dari $G$.

\section{Jenis-Jenis Graf}

Beberapa graf dikelompokkan berdasarkan ciri khusus dari setiap graf. Pada bagian ini akan dipaparkan beberapa jenis graf yang digunakan pada penelitian ini.

Definisi 5 Graf theta yang diperumum adalah graf yang terdiri dari dua titik kutub masingmasing berderajat $m$, dan terdiri $m$ buah lintasan dengan panjang $n$, dimana titik awal setiap lintasan bertetangga dengan satu titik kutub dan titik akhir setiap lintasan bertetangga dengan kutub yang lain. Graf theta yang diperumum dinotasikan dengan $\Theta(n, m)$.

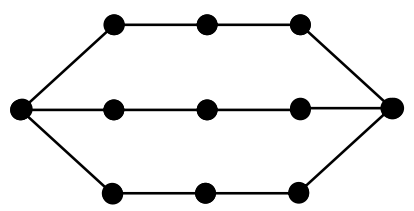

Gambar 1 Graf Theta yang Diperumum

Definisi 6 Graf titik potong blok (block-cutvertex) dari suatu graf $G$ adalah suatu graf $H$ yang titik-titiknya adalah blok dan titik potong dari $G, d u a$ titik bertetangga dari $H$ jika dan hanya jika titik yang satu adalah sebuah blok di $G$ dan titik yang lainnya adalah sebuah titik potong dari $G$ yang termuat dalam blok tersebut.

Definisi 7 Graf rantai (chain graph) yaitu sebuah graf blok $B_{1}, B_{2}, \ldots$, dan $B_{k}$ sedemikian sehingga untuk setiap $1 \leq i \leq k-1$ berlaku $B_{i}$ dan $B_{i+1}$ mempunyai suatu titik sekutu sehingga graf titik potong blok merupakan lintasan.

Definisi 8 Graf series parallel pada $G$ adalah suatu graf rantai dimana setiap bloknya merupakan graf theta yang diperumum . Graf Series parallel dinotasikan dengan $s p(m, r, l)$.

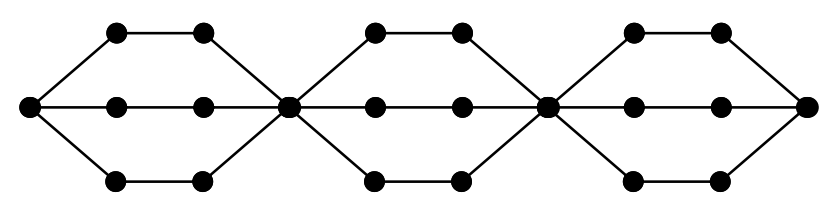

Gambar 2 Graf Series Parallel

\section{Pelabelan Graf}

Penelitian mengenai teori graf terus mengalami perkembangan. Salah satu pembahasan yang terus berkembang adalah 
pelabelan pada graf. Objek kajiannya berupa graf yang secara umum.

Definisi 9 Pelabelan graf adalah suatu fungsi yang memasangkan elemen-elemen graf ke suatu himpunan bilangan bulat positif, umumnya himpunan bilangan bulat positif.

Himpunan bilangan yang menjadi kodomain dari pelabelan disebut himpunan label. Suatu pelabelan graf disebut pelabelan titik jika domain dari fungsinya adalah himpunan titik, dan disebut pelabelan sisi jika domainnya adalah himpunan sisi dan jika domainnya adalah gabungan dari himpunan titik dan himpunan sisi maka pelabelat tersebut disebut pelabelan total.

Definisi 10 Bobot titik $v$ pada pelabelan total adalah label titik $v$ ditambah dengan jumlah semua label sisi yang terkait dengan $v$, yaitu

\section{Contoh 1}

$$
w t(v)=f(v)+\sum_{u v \in E} f(u v) .
$$

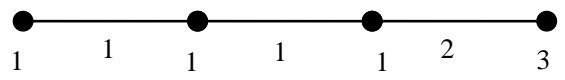

Gambar 3 Pelabelan Total pada $P_{4}$

Misalkan $f$ adalah pelabelan total pada $P_{4}$ seperti pada Gambar 3, yaitu:

$$
\begin{array}{ll}
f\left(v_{1}\right)=1 & f\left(v_{1} v_{2}\right)=1 \\
f\left(v_{2}\right)=1 & f\left(v_{2} v_{3}\right)=1 \\
f\left(v_{3}\right)=1 & f\left(v_{3} v_{4}\right)=2 \\
f\left(v_{4}\right)=3 . &
\end{array}
$$

Maka bobot titik $v_{1}, v_{2}, v_{3}$ dan $v_{4}$ masingmasing adalah

$$
\begin{aligned}
& w t\left(v_{1}\right)=f\left(v_{1}\right)+f\left(v_{1} v_{2}\right)=1+1=2 \\
& w t\left(v_{2}\right)=f\left(v_{2}\right)+f\left(v_{1} v_{2}\right)+f\left(v_{2} v_{3}\right) \\
& =1+1+1=3 \\
& w t\left(v_{3}\right)=f\left(v_{3}\right)+f\left(v_{2} v_{3}\right)+f\left(v_{3} v_{4}\right) \\
& =1+1+2=4 \\
& w t\left(v_{4}\right)=f\left(v_{4}\right)+f\left(v_{3} v_{4}\right)=3+2=5 \text {. }
\end{aligned}
$$

Pada tahun 2007, Baca memperkenalkan pelabelan tidak teratur lainnya yaitu pelabelan nilai total ketidakteraturan titik. Pada subbab ini akan dijelaskan definisi pelabelan total ketidakteraturan titik dan definisi nilai total ketidakteraturan titik.

Definisi 11 Misalkan $G(V, E)$ adalah graf sederhana. Pelabelan total $f: V \cup E \rightarrow$ $\{1,2,3, \ldots, k\}$ disebut suatu pelabelan $-k$ total tidak teratur titik (total vertex irregular $k$ labeling) pada graf G jika untuk setiap dua titik yang berbeda pada $V$, berlaku

$$
w t(x) \neq w t(y)
$$

dimana

$$
w t(x)=f(x)+\sum_{x u \in E(G)} f(x u) .
$$

Definisi 12 Nilai total ketidakteraturan titik (total vertex irregularity strength) dari $G$, dinotasikan dengan tvs $(G)$, adalah bilangan bulat positif terkecil $k$ sedemikian sehingga $G$ mempunyai suatu pelabelan-k total tidak teratur titik.

\section{Contoh 2}

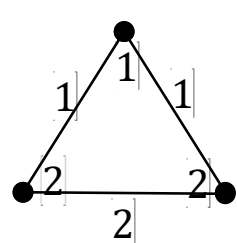

(a)

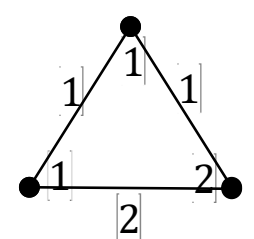

(b)

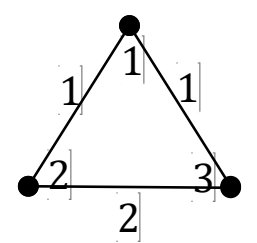

(c)
Gambar 4 Pelabelan Total pada $C_{3}$

Gambar 4 (a) bukan merupakan pelabelan total tidak teratur titik pada $C_{3}$, karena terdapat dua titik memiliki bobot yang sama dengan 4 . Sedangkan Gambar 4 (b) merupakan pelabelan2 total tidak teratur titik pada $C_{3}$ dan Gambar 4 (c) merupakan pelabelan-3 total tidak teratur titik pada $C_{3}$. Namun $C_{3}$ tidak mempunyai pelabelan-1 tidak teratur sehingga diperoleh $k$ yang terkecil adalah 2. Jadi nilai ketidakteraturan pada $C_{4}$ adalah 2 .

Nurdin dkk (2010) memberikan batas bawah untuk nilai total ketidakteraturan titik pada, sebagai berikut:

Teorema 1 (Nurdin, dkk., 2010)

Misalkan $G$ adalah suatu graf yang mempunyai $n_{i}$ titik berderajat $i$ dengan $i=$ 
$\delta, \delta+1, \delta+2, \ldots, \Delta$ dengan $\delta$ dan $\Delta$ adalah derajat minimum dan maksimum titik dari $G$, maka

$\operatorname{tvs}(G) \geq \operatorname{maks}\left\{\left\lceil\frac{\delta+n_{\delta}}{\delta+1}\right\rceil,\left\lceil\frac{\delta+n_{\delta}+n_{\delta+1}}{\delta+2}\right\rceil, \ldots,\left\lceil\frac{\delta+\sum_{i=\delta}^{\Delta} n_{i}}{\Delta+1}\right\rceil\right\}$.

\section{METODOLOGI}

Adapun langkah-langkah dalam penelitian ini adalah sebagai berikut:

\section{Identifikasi Masalah}

Identifikasi masalah dilakukan dengan cara mengumpulkan beberapa jurnal ilmiah dan buku yang berkaitan dengan nilai total ketidakteraturan titik pada graf sebagai referensi. Selanjutnya menentukan fokus pembahasan penelitian

2. Studi Literatur

Mengkaji secara mendalam jurnal ilmiah dan buku yang akan dikembangkan pada penelitian.

3. Menentukan Batas Bawah

Batas bawah nilai total ketidakteraturan titik pada graf Series Parallel $s p(m, 3,3)$ dianalisis berdasarkan sifat-sifat dan karakteristik graf, banyaknya derajat titik dan banyaknya jumlah titik pada graf.

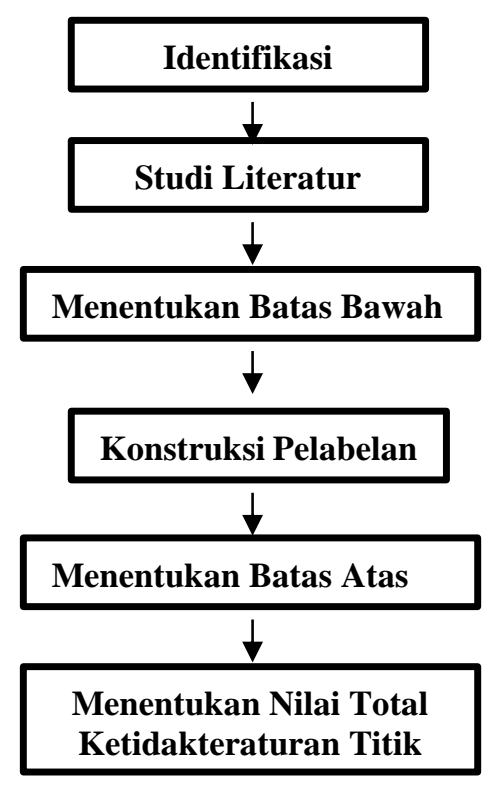

Gambar 5. Diagram Alur Kerja

4. Melakukan Konstruksi Pelabelan

Memberikan label setiap titik dan sisi pada graf dan menentukan bobot titik berdasarkan definisi. Kemudian mendefinisikan himpunan titik dan sisi $f: V \cup E \rightarrow\{1,2, \ldots k\}$ sehingga $k$ adalah bilangan bulat positif terkecil.

5. Menentukan Batas Atas

Mengidentifikasi label terbesar dari konstruksi pelabelan sebagai batas Atas.

6. Menentukan Nilai Total Ketidakteraturan

Titik

Menghitung bobot setiap titik dan memastikan bahwa bobot setiap titik berbeda

7. Penarikan Kesimpulan

Setelah menentukan batas bawah dan batas atas dengan melakukan konstruksi pelabelan, maka selanjutnya melakukan penarikan kesimpulan terhadap nilai total ketidakteraturan titik.

8. Penyusunan Laporan

Penyusunn laporan berdasarkan tahapan penelitian dapat dilihat pada gambar 5

\section{HASIL DAN PEMBAHASAN}

\section{Graf Series Parallel}

Graf series parallel didefinisikan sebagai berikut:

\section{Definisi 13 (Rajasingh,2015)}

Graf series parallel pada $G$ adalah suatu graf rantai dimana setiap bloknya merupakan graf theta yang diperumum. Graf Series parallel dinotasikan dengan $\operatorname{sp}(m, r, l)$.

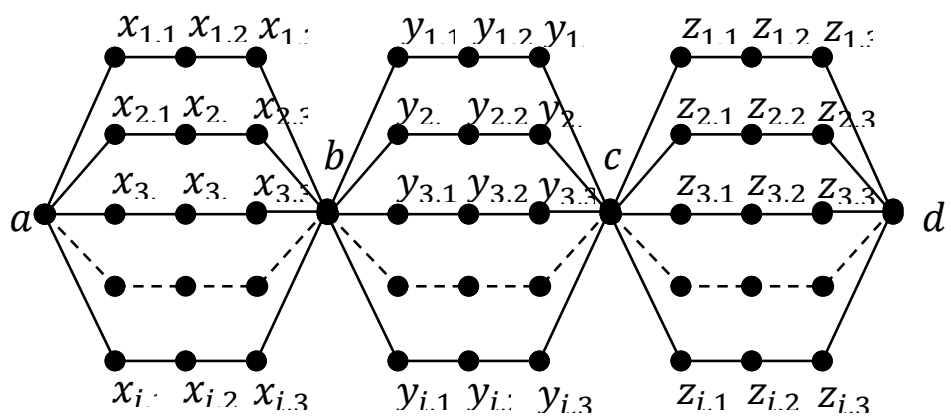

Gambar 6 Graf Series Parallel $s p(m, 3,3)$

Gambar 6 menunjukkan graf Series Parallel untuk $r=3$ dan $l=3$. Selanjutnya didefinisikan himpunan titik $V$ dan himpunan sisi $E$ sebagai berikut:

$$
\begin{aligned}
& V=\left\{x_{i, j}, y_{i, j}, z_{i, j} \mid i=1,2, \ldots, m, j=1,2,3\right\} \cup \\
& \{a, b, c, d\} \text { dan } \\
& E=\left\{x_{i, 1} x_{i, 2}, x_{i, 2} x_{i, 3}, y_{i, 1} y_{i, 2}, y_{i, 2} y_{i, 3}, z_{i, 1} z_{i, 2}, z_{i, 2} z_{i, 3}\right\} \\
& \cup\left\{x_{i, 1} a, x_{i, 3} b, y_{i, 1} b, y_{i, 3} c, z_{i, 1} c, z_{i, 3} d\right\}
\end{aligned}
$$

dimana $i=1,2, \ldots, m$ 


\section{Nilai Total Ketidakteraturan Titik Series} Parallel sp $(m, 3,3)$

Dalam penentuan nilai total ketidakteraturan titik pada pada graf series parallel, diawali dengan memeberikan label titik dan label sisi pada graf series parallel $s p(m, 3,3)$ untuk $m=3,4,5$ gengan mempertimbangkan hal berikut:

1. Batas bawah dengan menggunakan Teorema 1

2. Batas atas dengan pemberian label pda titik dan sisi

3. Bobot pada setiap titik berbed

4. Mempertahankan pola pemberian label titik dan sisi

Berdasarkan Teorema 1 untuk $m=3,4,5$ batas bawah nilai total ketidakteraturan titik pada Series Parallel $s p(m, 3,3)$ dapat dilihat pada Tabel 1.

Tabel 1 Batas bawah Pelabelan Total $s p(m, 3,3)$

\begin{tabular}{|c|c|c|c|c|}
\hline$m$ & $\delta$ & $\boldsymbol{n}_{\delta}$ & {$\left[\frac{\boldsymbol{\delta}+\boldsymbol{n}_{\boldsymbol{c}}}{\boldsymbol{\delta}+\boldsymbol{1}}\right.$} & $\leq \operatorname{tvs}(\operatorname{sp}(m, 3,3))$ \\
\hline 3 & 2 & 27 & & 10 \\
\hline 4 & 2 & 36 & & 13 \\
\hline 5 & 2 & 45 & & 16 \\
\hline
\end{tabular}

Selanjutnya untuk menentukan batas atasnya, maka titik dan sisi pada graf Series Parallel untuk $m=3,4,5$ diberi label sebagai berikut.

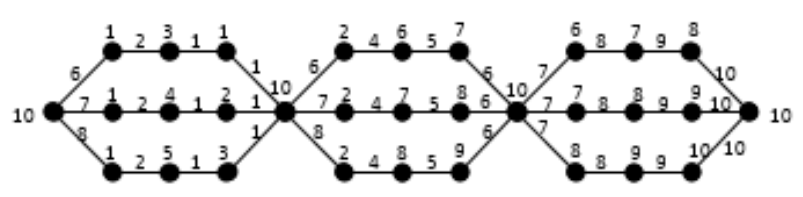

Gambar 7 Pelabelan-10 Total $s p(3,3,3)$

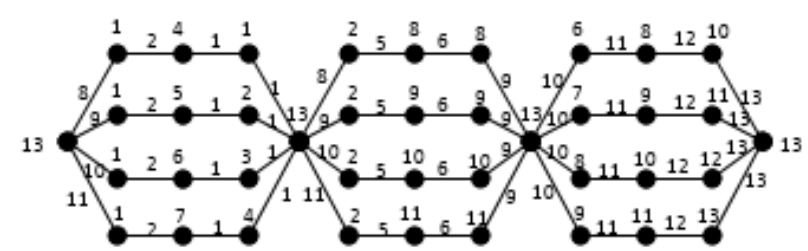

Gambar 8 Pelabelan-13 Total $s p(4,3,3)$

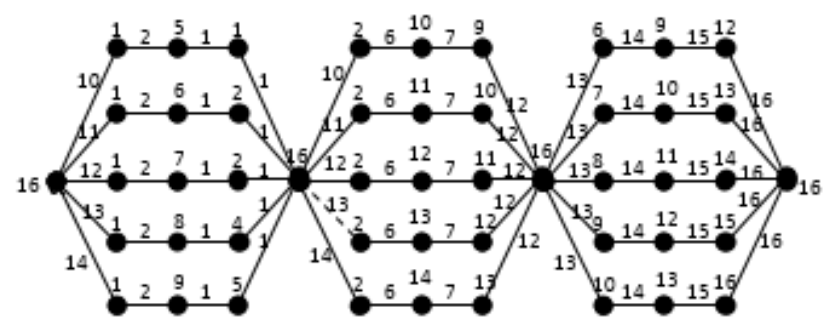

Gambar 9 Pelabelan-16 Total $s p(5,3,3)$

Berdasarkan Tabel 1, diasumsikan bahwa nilai total ketidakteraturan titik pada graf Series Parallel yaitu $\operatorname{tvs}(s p(m, 3,3))=3 m+1$. Hasil ini dituliskan pada Teorema 2 yang disertai dengan buktinya.

Teorema 2 Untuk $m \geq 3$, maka nilai total ketidakteraturan titik pada graf Series Parallel $s p(m, 3,3)$ adalah

\section{Bukti:}

$$
\operatorname{tvs}(\operatorname{sp}(m, 3,3))=3 m+1
$$

Untuk membuktikan bahwa $\operatorname{tvs}(\operatorname{sp}(m, 3,3))=$ $3 m+1$ maka digunakan Teorema 1. Derajat minimum dari $s p(m, 3,3)$ adalah $\delta=2$, banyaknya titik yang berderajat 2 adalahn $n_{2}=$ $9 m$. Selanjutnya derajat terkecil kedua adalah $m$ dengan banyak titik $m$ adalah $n_{m}=2$, dan derajat maksimum adalah $2 m$ dengan banyak titik $n_{2 m}=2$. Maka berdasarkan Teorema 1 diperoleh

$\operatorname{tvs}(G) \geq \operatorname{maks}\left\{\left\lceil\frac{\delta+n_{\delta}}{\delta+1}\right\rceil,\left\lceil\frac{\delta+n_{\delta}+n_{\delta+1}}{\delta+2}\right\rceil, \ldots,\left\lceil\frac{\delta+\sum_{\delta}^{\Delta} n_{i}}{\Delta}\right\rceil\right\}$.

\section{Sehingga}

$\operatorname{tvs}(\operatorname{sp}(m, 3,3))$

$\geq \operatorname{maks}\left\{\left\lceil\frac{2+9 m}{3}\right\rceil,\left\lceil\frac{2+2+9 m}{m}\right\rceil,\left\lceil\frac{2+2+2+9 m}{2 m}\right\rceil\right\}$

$=\operatorname{maks}\left\{\left\lceil\frac{2+9 m}{3}\right\rceil,\left\lceil\frac{4+9 m}{m}\right\rceil,\left\lceil\frac{6+9 m}{2 m}\right\rceil\right\}$.

Untuk $m \geq 3$ maka

$$
\operatorname{tvs}(\operatorname{sp}(m, 3,3))
$$

$\geq \operatorname{maks}\left\{\left\lceil\frac{2+9 m}{3}\right\rceil,\left\lceil\frac{4+9 m}{m}\right\rceil,\left\lceil\frac{6+9 m}{2 m}\right\rceil\right\}$

$$
\begin{aligned}
\operatorname{tvs}(\operatorname{sp}(m, 3,3)) & =\left\lceil\frac{2+9 m}{3}\right\rceil \\
& =\left\lceil\frac{2}{3}+\frac{9 m}{3}\right\rceil \\
& =1+3 m .
\end{aligned}
$$


Selanjutnya akan ditunjukkan bahwa

$$
\operatorname{tvs}(\operatorname{sp}(m, 3,3)) \leq 3 m+1 \text {. }
$$

Untuk membuktikan hal tersebut dilakukan konstruksi suatu pelabelan total tidak teratur titik pada Graf Series Parallel $s p(m, 3,3)$.

\section{Konstruksi suatu pelabelan total $f$ pada} $s p(m, 3,3)$

Untuk $i=1,2, \ldots, m$ maka konstruksi pelabelan total sebagai berikut.

$$
\begin{aligned}
& f\left(x_{i, 1}\right)=1 \\
& f\left(x_{i, 2}\right)=m+i-1 \\
& f\left(x_{i, 3}\right)=i \\
& f\left(y_{i, 1}\right)=2 \\
& f\left(y_{i, 2}\right)=2 m+i-1 \\
& f\left(y_{i, 3}\right)=m+i+3 \\
& f\left(z_{i, 1}\right)=i+5 \\
& f\left(z_{i, 2}\right)=m+i+3 \\
& f\left(z_{i, 3}\right)=2 m+i+1 \\
& f(a)=f(b)=f(c)= \\
& f\left(x_{i, 1} x_{i, 2}\right)=2 \\
& f\left(x_{i, 2} x_{i, 3}\right)=1 \\
& f\left(y_{i, 1} y_{i, 2}\right)=m+1 \\
& f\left(y_{i, 2} y_{i, 3}\right)=m+2 \\
& f\left(z_{i, 1} z_{i, 2}\right)=3 m-2 \\
& f\left(z_{i, 2} z_{i, 3}\right)=3 m-1 \\
& f\left(x_{i, 1} a\right)=2 m+i-1 \\
& f\left(x_{i, 3} b\right)=1 \\
& f\left(y_{i, 1} b\right)=2 m+i-1 \\
& f\left(y_{i, 3} c\right)=3 m-3 \\
& f\left(z_{i, 1} c\right)=3 m-2 \\
& f\left(z_{i, 3} d\right)=3 m+1
\end{aligned}
$$$$
f(a)=f(b)=f(c)=f(d)=3 m+1
$$

Perhatikan bahwa bobot pada setiap titik $s p(m, 3,3)$ berdasarkan pelabelan , untuk $i=$ $1,2, \ldots, m$ sebagai berikut.

$$
\text { 1. } \begin{aligned}
w t\left(x_{i, 3}\right)= & f\left(x_{i, 3}\right)+f\left(x_{i, 2} x_{i, 3}\right)+f\left(x_{i, 3} b\right) \\
& =i+1+1 \\
& =i+2
\end{aligned}
$$

2. $w t\left(x_{i, 2}\right)=f\left(x_{i, 2}\right)+f\left(x_{i, 1} x_{i, 2}\right)+f\left(x_{i, 2} x_{i, 3}\right)$ $=(m+i-1)+(2)+(1)$

$$
=m+i+2
$$

3. $w t\left(x_{i, 1}\right)=f\left(x_{i, 1}\right)+f\left(x_{i, 1} x_{i, 2}\right)+f\left(x_{i, 1} a\right)$

$$
=(1)+(2)+(2 m+i-1)
$$

$$
=2 m+i-2
$$

4. $w t\left(y_{i, 1}\right)=f\left(y_{i, 1}\right)+f\left(y_{i, 1} b\right)+f\left(y_{i, 1} y_{i, 2}\right)$ $=(2)+(2 m+i-1)+(m+1)$

$$
=3 m+i+2
$$

5. $w t\left(y_{i, 2}\right)=f\left(y_{i, 2}\right)+f\left(y_{i, 1} y_{i, 2}\right)+f\left(y_{i, 2} y_{i, 3}\right)$ $=(2 m+i-1)+(m+1)+(m+2)$ $=4 m+i+2$

6. $w t\left(y_{i, 3}\right)=f\left(y_{i, 3}\right)+f\left(y_{i, 2} y_{i, 3}\right)+f\left(y_{i, 3} c\right)$ $=(m+i+3)+(m+1)+(3 m-3)$ $=5 m+i+1$

7. $w t\left(z_{i, 1}\right)=f\left(z_{i, 1}\right)+f\left(z_{i, 1} c\right)+f\left(z_{i, 1} z_{i, 2}\right)$ $=(i+5)+(3 m-2)+(3 m-2)$ $=6 m+i+1$

8. $w t\left(z_{i, 2}\right)=f\left(z_{i, 2}\right)+f\left(z_{i, 1} z_{i, 2}\right)+f\left(z_{i, 2} z_{i, 3}\right)$ $=(m+i+3)+(3 m-2)+(3 m-1)$ $=7 m+i$

9. $w t\left(z_{i, 3}\right)=f\left(z_{i, 3}\right)+f\left(z_{i, 2} z_{i, 3}\right)+f\left(z_{i, 3} d\right)$ $=(2 m+i+1)+(3 m-1)+(3 m+1)$ $=8 m+i+1$

10. $w t(a)=f(a)+\sum_{i=1}^{m} f\left(x_{i, 1} a\right)$

$$
=(3 m+1)+\sum_{i=1}^{m}(2 m+i-1)
$$

11. $w t(b)=f(b)+\sum_{i=1}^{m} f\left(x_{i, 3} b\right)+\sum_{i=1}^{m} f\left(y_{i, 1} b\right)$

$$
\begin{aligned}
& =(3 m+1)+\sum_{i=1}^{m} 1+\sum_{i=1}^{m}(2 m+i-1) \\
& =(4 m+1)+\sum_{i=1}^{m} 1+\sum_{i=1}^{m}(2 m+i-1)
\end{aligned}
$$

12. $w t(d)=f(d)+m\left(f\left(z_{i, 3} d\right)\right)$

$$
\begin{aligned}
& =(3 m+1)+m(3 m+1) \\
& =3 m^{2}+4 m+1
\end{aligned}
$$

13. $w t(c)=f(c)+m\left(f\left(y_{i, 3} c\right)\right)+m\left(f\left(z_{i, 1} c\right)\right)$

$$
\begin{aligned}
& =(3 m+1)+m(3 m-3)+m(3 m-2) \\
& =6 m^{2} 2 m-2 m+1 .
\end{aligned}
$$

Berdasarkan definisi bobot titik tersebut, diperoleh

$w t\left(x_{1,3}\right)<w t\left(x_{2,3}\right)<\cdots<w t\left(x_{m, 3}\right)<$ $w t\left(x_{1,2}\right)<w t\left(x_{2,2}\right)<\cdots<w t\left(x_{m, 2}\right)<$ $w t\left(x_{1,1}\right)<w t\left(x_{2,1}\right)<\cdots<w t\left(x_{m, 1}\right)<$ $w t\left(y_{1,1}\right)<w t\left(y_{2,1}\right)<\cdots<w t\left(y_{m, 1}\right)<$ $w t\left(y_{1,2}\right)<w t\left(y_{2,2}\right)<\cdots<w t\left(y_{m, 2}\right)<$ $w t\left(y_{1,3}\right)<w t\left(y_{2,3}\right)<\cdots<w t\left(y_{m, 3}\right)<$ $w t\left(z_{1,1}\right)<w t\left(z_{2,1}\right)<\cdots<w t\left(z_{m, 1}\right)<$ $w t\left(z_{1,2}\right)<w t\left(z_{2,2}\right)<\cdots<w t\left(z_{m, 2}\right)<$ $w t\left(z_{1,3}\right)<w t\left(z_{2,3}\right)<\cdots<w t\left(z_{m, 3}\right)<$ $w t(a)<w t(b)<w t(d)<w t(c)$. 
Sehingga dapat disimpulkan bahwa bobot setiap titik pada $s p(m, 3,3)$ berbeda. Maka $f$ yang dikonstruksikan tersebut merupakan suatu pelabelan tidak teratur pada $s p(m, 3,3)$.

Selanjutnya akan ditunjukkan bahwa label terbesar yang digunakan adalah $t$ sebagai berikut. Misalkan $t=3 m+1$.

Untuk $i=1,2, \ldots, m$ dan $m \geq 3$

1. $f\left(x_{i, 1}\right) \leq f\left(x_{m, 1}\right)=1 \leq t$

2. $f\left(x_{i, 2}\right) \leq f\left(x_{m, 2}\right)=(m+m-1)=2 m-1 \leq t$

3. $f\left(x_{i, 3}\right) \leq f\left(x_{m, 3}\right)=m \leq t$

4. $f\left(y_{i, 1}\right) \leq f\left(y_{m, 1}\right)=2 \leq t$

5. $f\left(y_{i, 2}\right) \leq f\left(y_{m, 2}\right)=2 m+m-1=3 m-1 \leq t$

6. $f\left(y_{i, 3}\right) \leq f\left(y_{m, 3}\right)=m+m+3=2 m \leq t$

7. $f\left(z_{i, 1}\right) \leq f\left(z_{m, 1}\right)=m+5 \leq t$

8. $f\left(z_{i, 2}\right) \leq f\left(z_{m, 2}\right)=m+m+3=2 m+3 \leq t$

9. $f\left(z_{i, 3}\right) \leq f\left(z_{m, 3}\right)=2 m+m+1=3 m+1 \leq t$

10. $f(a)=f(b)=f(c)=f(d)=3 m+1 \leq t$

11. $f\left(x_{i, 1} x_{i, 2}\right) \leq f\left(x_{m, 1} x_{m, 2}\right)=2 \leq t$

12. $f\left(x_{i, 2} x_{i, 3}\right) \leq f\left(x_{m, 2} x_{m, 3}\right)=1 \leq t$

13. $f\left(y_{i, 1} y_{i, 2}\right) \leq f\left(y_{m, 1} y_{m, 2}\right)=m+1 \leq t$

14. $f\left(y_{i, 2} y_{i, 3}\right) \leq f\left(y_{m, 2} y_{m, 3}\right)=m+2 \leq t$

15. $f\left(z_{i, 1} z_{i, 2}\right) \leq f\left(z_{m, 1} z_{m, 2}\right)=3 m-2 \leq t$

16. $f\left(z_{i, 2} z_{i, 3}\right) \leq f\left(z_{m, 2} z_{m, 3}\right)=3 m-1 \leq t$

17. $f\left(x_{i, 1} a\right) \leq f\left(x_{m, 1} a\right)=2 m+m-1=$ $3 m-1 \leq t$

18. $f\left(x_{i, 3} b\right) \leq f\left(x_{m, 3} b\right)=1 \leq t$

19. $f\left(y_{i, 1} b\right) \leq f\left(y_{m, 1} b\right)=2 m+m-1=$ $3 m-1 \leq t$

20. $f\left(y_{i, 3} c\right) \leq f\left(y_{m, 3} c\right)=3 m-3 \leq t$

21. $f\left(z_{i, 1} c\right) \leq f\left(z_{m, 1} c\right)=3 m-2 \leq t$

22. $f\left(z_{i, 3} d\right) \leq f\left(z_{m, 3} d\right)=3 m+1 \leq t$

Dengan demikian $f$ merupakan suatu pelabelan $-t$ total tidak teratur titik dengan $t=$ $3 m+1, \quad$ untuk $\quad m \geq 3$. Artinya $\operatorname{tvs}(\operatorname{sp}(m, 3,3)) \leq 3 m+1$. $\operatorname{tvs}(\operatorname{sp}(m, 3,3)) \geq 3 m+1$

Karena

$\operatorname{tvs}(\operatorname{sp}(m, 3,3)) \leq 3 m+1$, maka

$$
\operatorname{tvs}(\operatorname{sp}(m, 3,3))=3 m+1
$$

\section{KESIMPULAN}

Berdasarkan hasil dan pembahasan penelitian, diperoleh kesimpulan bahwa nilai totak ketidakteraturan titik pada Graf Series Parallel untuk $m \geq 3$ yaitu $\operatorname{tvs}(s p(m, 3,3))=$ $3 m+1$. Pembahasan mengenai pelabelan total tidak teratur titik masih terbuka bagi peneliti lain untuk melanjutkan penelitian ini dan dapat juga melakukan penelitian yang sejenis dengan jenis-jenis graf yang berbeda.

\section{DAFTAR PUSTAKA}

[1] Ahmad, A., Bača, M., \& Bashir, Y. (2014). Total vertex irregularity strength of certain classes of unicyclic graphs. Bulletin mathématique de la Société des Sciences Mathématiques de Roumanie, 147-152.

[2] Ahmad, A., Baca, M., \& Siddiqui, M. K. (2014). Irregular total labeling of disjoint union of prisms and cycles. Australas. $J$ Comb., 59, 98-106

[3] Bača, M., Miller, M., \& Ryan, J. (2007). On irregular total labellings. Discrete mathematics, 307(11-12), 1378-1388.

[4] Kotzig, A., \& Rosa, A. (1970). Magic valuations of finite graphs. Canadian Mathematical Bulletin, 13(4), 451-461

[5] Marzuki, C. C., Laraza, L., \& Aryani, F. (2020).

NILAI

TOTAL

KETAKTERATURAN TITIK PADA

GRAF SERI PARALEL sp (m, 1, 3). Jurnal Sains Matematika dan Statistika, 6(2), 113123.

[6] Rajasingh, I., Rajan, B., \& Annama, V. (2012). On total vertex irregularity strength of triangle related graphs. Annals of Pure and Applied Mathematics, 1(2), 108-116

[7] Rajasingh, I., \& Arockiamary, S. T. (2015). Total edge irregularity strength of series parallel graphs. International Journal of Pure and Applied Mathematics, 99(1), 1121.

[8] Riskawati, Nurdin, dan Kasmirah, (2019), "Nilai Total Ketidakteraturan Titik pada Graf Series Parallel sp $(m, r, 2)$ " (Axiomath 
:Jurnal Matematika dan Aplikasinya, Vol. 1 No. 2

[9] Simanjuntak, R., Susilawati, S., \& Baskoro, E. T. (2020). Total vertex irregularity strength for trees with many vertices of degree two. Electron. J. Graph Theory Appl., 8(2), 415-421.

[10] Stewart, B. M. (1966). Magic graphs. Canadian Journal of Mathematics, 18, 1031-1059.

[11]Wallis, W. D. (2001). Magic graphs. Springer Science \& Business Media. 